\title{
The Effect of Gender Mainstreaming on Income of Turkish Independent Audit Organizations within the Scope of Sustainable Development
}

Submitted 17/03/20, 1st revision 14/04/20, 2nd revision 15/05/20, accepted 20/07/20

\author{
Esra Atabay ${ }^{1}$, Engin Boztepe ${ }^{2}$
}

\begin{abstract}
:
Purpose: This study focuses on gender mainstreaming that is one of the objectives set for sustainable development. The study aims to determine whether presence of directresses in senior management of independent audit organizations has any effect on income of such organizations.

Approach/Methodology/Design: The study sample is formed by independent audit organizations that operate in Turkey and have authority of "KAYIK (public interest entities)". The Year 2018 transparency reports of said independent audit organizations are reviewed in terms of date of establishment, total equity, capital ratios and numbers of male and female partners, number of key directors and directresses, presence of chairman or chairwoman, number of Public Interest Entities served, income arising out of audit services and total income of the audit organization. Resultant data is subjected to frequency analysis using SPSS statistics software. It is followed by univariate simple linear regression, unpaired $t$ test and multivariate linear regression in line with the created study models.

Findings: The findings revealed out that each gender-related independent variable had statistically significant effect on total income, but the significance level was not lost and its effect could be maintained only for the independent variable "number of key directresses", when independent variables, such as time since date of establishment, number of clients (number of Public Interest Entities audited), total equity and being a member of International Audit Network, were also taken into consideration.

Originality/Value It is obvious that, within the scope of the gender mainstreaming goals, women's leadership roles are gradually increasing and they are contributing to economic development in this direction. However, it is a fact that it is not yet at the desired level.
\end{abstract}

Keywords: Sustainable Development, gender mainstreaming, independent audit, independent audit organizations.

JEL Codes: M42, J16, Q56.

Research Type: Research Article

${ }^{1}$ Corresponding Author, Trabzon University, Vakfikebir Vocational School, ORCID ID: 0000-0002-6855-7521,e-mail: eatabay@trabzon.edu.tr

${ }^{2}$ Ardahan University, School of Health Sciences,

ORCID ID: 0000-0003-0775-6129, e-mail: enginboztepe@ardahan.edu.tr 


\section{Introduction}

Sustainability is a concept that was first introduced by the World Council of Churches (WCC) in 1974 and that was proposed by Western environmentalists because countries that fight hunger and poverty in some parts of the world pose environmental hazards. The concept of sustainable development was used for the first time in 1980 and finally gained its modern use with the report titled "Our Common Future" in the Brundtland Report prepared by the World Environment and Development Commission in 1987 (Dresner, 2002). In the report, in general, eradication of poverty, ensuring equality in the distribution of benefits from natural resources, population control, and the development of environmentally friendly technologies are directly associated with the principle of sustainable development (MFA, 2002). Sustainable development focuses on ensuring that today's resources are used without wasting and transferred to future generations without a decrease. In this context, economical problems are tried to be tackled, especially in developing countries, while solutions are sought for environmental problems. Keeping up with advancing technology, science and innovations are of utmost importance for the development of countries. However, the environmental damage has reached undeniable levels during the adaptation process to developments. In addition to combating poverty, environmental and social resources are also protected within the scope of sustainable development. The concept of "Sustainable Development", which has social, ecological, economic, spatial and cultural dimensions, means programming the life and development of today and the future in a way that allows to meet the needs of future generations and to develop them by establishing a balance between human and nature (GAP, Sustainable development program) (GAP, 2002).

The Millennium Development Goals which were determined to eliminate poverty in 2000 were replaced by Sustainable Development Goals. There are 17 of these goals and were determined at the United Nations Sustainable Development Conference held in Rio de Janerio in 2012. The goals set are interrelated. In addition to economic targets such as hunger and poverty, which the Millennium Development Goals focused on, it contains new areas such as climate change, economic inequality, innovation, sustainable consumption, peace, and justice, as well (UNDP TR, 2016). The United Nations Development Program aims to eradicate poverty and hunger, to eliminate AIDS, tuberculosis, malaria, and other infectious diseases, to provide general health care, safe and accessible medicines, and vaccines to all, and to support vaccine research and development. Besides, provision of free primary and secondary education, provision of equal access to cost-effective vocational education, and elimination of gender and income inequalities are also among the goals. Clean water, accessible and clean energy sources, protection of water and land life, prevention of global warming, elimination of digital inequalities, prevention of violence, the establishment of a universal and equitable trade system, reduction of inequalities and implementation of recycling projects will ensure the continuity of 
the countries in not only economic and social but environmental aspects as well (UNDP TR, 2016).

This study is about gender equality, which is determined within the scope of sustainable development goals. Sustainable development aims to prevent discrimination against women and girls, to encourage women leaders, and to provide women with equal rights over economic resources such as land and property (United Nations Development Program). This study focuses on "encouraging women leaders", which is targeted by gender equality. TEPAV (The Economic Policy Research Foundation of Turkey) publishes a report, the first of which was published in 2014, titled "Gender Equality Ratings for 81 provinces". In this report, provinces are ranked according to their inequality levels. The second version of the report was prepared in 2016 and a gender equality index and women's empowerment index were created on a provincial basis. In the third version, using data from the years 2016-2017, the nature of the change in the gender inequality rating of Turkey was shown compared with the 2012-2015 period. Accordingly, it is seen that the gender inequality index scores of Turkey fell down, the range of inequality considerably decreased compared to the previous period and that progress was made (Kavas, 2018). Women face a biased attitude in business life as in all fields of life, and this attitude often creates a glass ceiling effect on women in working life. The inclusion of the women's labor force in business life is of utmost importance for social welfare and development. When the local and international literature on the subject is examined, it can be seen that the results obtained vary.

When national literature is analyzed, it is seen that there are many studies on women's involvement in business life. In relation to the subject of this study, studies revealing whether the involvement of women in business life is effective on the performance of the companies they work for have been examined within the scope of the literature. Karayel and Doğan (2014) examined the relationship between the gender equality in the boards of directors of the companies operating in the BIST 100 index and their financial performance and found that gender diversity had a positive effect on profitability. The study conducted by Karabiyik (2012) concluded that women's employment is important in terms of social development, but women's employment cannot be increased at the desired level due to the current social structure and policies pursued in the economy. Alhan and Yuksel (2018) investigated the effect of female employees on the size and profitability of banks and found that the proportion of female employees in Turkish banks was positively related to both profitability and size of the bank in the long term. Ahmadi, Nakaa and Bouri (2018) revealed a statistically significant relationship between the gender of the board members and the financial performance of the firm. The study conducted by Ocak (2013) similarly revealed that the firm's active profitability increases as the proportion of women in the board of directors and senior management increases. Despite this positive relationship, there are also studies indicating that women being in senior management affect the profitability of the firm negatively (Postula, Irodenko, and Dubel, 2020). 
As a matter of fact, Menteş (2011) found a negative relationship between gender diversity in the boards of directors of the companies operating the Istanbul Stock Exchange Industry Index and their financial performance. In the analysis using Tobin's q and ROA, a negative and significant relationship with Tobin's q was detected, while a statistically significant relationship with ROA could not be revealed. Atilgan (2017) examined the relationship between the proportion of female members in the board of directors of companies operating in BIST and their financial performance. The analysis determined a poor and negative relationship between EBITDA margin and return of sales (ROS). İlhan Nas et al. (2019) examined the general profile of female members in the joint board and its impact on financial performance in the affiliates of Turkish business groups. They found a negative relationship between financial performance and the proportion of female members in joint boards. There are also studies showing that the presence of female managers in the top management does not affect the financial performance of the enterprises. Savaskan (2020) analyzed the indexes in 2010-2017 financially in terms of gender inequality in the board of directors of the manufacturing industry sector in the BIST 100 index. According to the results obtained from the analyses, it was determined that the presence of female members in the boards of directors of the firms operating in the manufacturing industry in the BIST 100 index in Turkey had no impact on the Return of Equity (ROE) Return on Assets (ROA). Özataç (2011) analyzed the relationship between the Return on Assets of the banks operating in Turkey and the number of female managers in the top management and the board of directors. As a result of the analysis, it was determined that the number of female executives in the top management is quite low and does not have an impact on financial performance.

Examination of the international literature showed that there were a large number of studies showing that women executives created a positive impact on firm performance while there were also a small number of studies showing that they had a negative or no impact on firm performance.

$\mathrm{Li}$ and $\mathrm{Li} \mathrm{(2020)}$ investigated the impact of women board chairpersons on audit committees in terms of financial irregularities of firms listed in China. The results showed that the women board chairpersons were more inclined to reduce financial irregularities than men. Martinez and Rambaud (2019) investigated the impact of the percentage of women on the boards of firms indexed in IBEX35 of the Spanish Stock Exchange between 2003 and 2017. Findings obtained from the study showed that the increasing number of women in the boards was positively associated with financial performance. A study involving large-scale companies in Europe was carried out by Green and Homroy (2018). In the study, it was determined that women representatives in the committees of the board had a strong and positive effect on economic performance. Conyon and $\mathrm{He}$ (2017) collected data using more than 3000 US companies between 2007 and 2014. The data showed that the presence of women in the boards of directors had a positive effect on firm performance. Liu et al. (2014) examined the relationship between gender diversity on the boards of 
companies listed in the Chinese Stock Exchange and the firm performance between 1999 and 2011 and found a positive and significant relationship between them. Compared to female independent directors, they concluded that female executive directors had a stronger impact on firm performance. Kallianiotis et al. (2020) have examined speculation and exchange rates for the US market with reference to this issue. Rovers (2011) analyzed the financial performances of German companies with and without women on their boards of directors. The analysis covered 99 firms in the German Women's Board Index and revealed that firms with female directors performed better than those without. Although there are many studies showing that female managers have a positive effect on firm performance, Yang et al. (2019) found negative effects. The study examined the main sources of claims in the current literature on the effects of female managers on firm performance in Norway. It was concluded from the study that female representatives had a negative impact on firm performance and risk. Chauhan and Dey (2017), on the other hand, found that female managers had no effect on firm performances. Chauhan and Dey examined the impact of female managers on the financial performance of firms in India. They found that gender diversity did not have any impact on firms.

This study differs from the domestic and foreign studies mentioned above in that it sector-oriented. In this study, the effect of the presence of female executives in top management in the independent audit sector on the revenues of the audit firm was examined. There is a similar study to this, which was conducted by Bozcuk (2018). In her study, addressed the case for gender diversity on the level of cap auditors in independent audit firms and investigated its impact on the total revenue of the audit firm using regression analysis. According to his findings, he found a positive and statistically significant relationship between gender diversity and the revenue of the audit firm. However, when other factors affecting the audit firm's revenue were included in the analysis, it was observed that the presence of the female cap auditor lost its effect on the revenue of the audit firm. This study is based on the firm's partnership structure, key management staff, and the gender of the chairman of the board of directors as gender variables. The positions listed include all positions at the senior management level of the independent audit firm. Our study differs from that of Bozcuk, which took into consideration only the number of cap auditors in that it analyzed more than one variable that constitutes the top management level.

\section{Materials and Methods}

\subsection{Purpose and Scope of the Study}

The aim of this study is to address gender mainstreaming, which is within the scope of sustainable development goals in terms of independent audit institutions and to determine whether the presence of female managers in the top management has an effect on the revenue of the audit firm. The sample of the study consists of independent auditing firms operating in our country and authorized by the Public Oversight Accounting and Auditing Standards Authority (KGK) to audit Public 
Interest Entities (PIE). Audit organizations with PIE audit authorization that conduct PIE audits in the relevant year have to publish a transparency report. For this reason, the main body of research comprises of independent auditing institutions that meet this condition. In this context, 5 websites of 125 firms could not be accessed, and it was found that 41 companies did not publish transparency reports since they did not audit PIEs. The remaining 79 companies published transparency reports. However, it was observed that 5 of these companies did not carry out PIE audits in the relevant year but still published a transparency report. Since the criterion of transparency report publishing was used as a base in determining the companies to be included in the study, 79 companies that published transparency reports in 2018 were included in the research.

\subsection{Data Collection and Analysis Method}

The data used in the study were obtained from the official website of KGK, using the current transparency reports under the heading "Transparency Reports of Independent Audit Firms and Disclosures on Their Transparency Reports". Transparency reports were analyzed in terms of the date of establishment of the audit firm, total capital amounts, the capital ratios of male and female partners, the number of male and female partners, the number of male and female key executives, the gender of the chairperson of the board of directors, whether it is a member of the international audit network, and the country of affiliation if it has a membership, the number of PIEs it provides audit service for, revenues of audit service and the total revenues of the audit firm. The data obtained were combined in the Microsoft Excel program and the duration of the firm's activity was calculated based on the firm's date of establishment, and the ratio of the audit revenues based on the audit service revenues and the total revenue. The data obtained were analyzed using SPSS. First, the frequencies related to the audit firms within the scope of the research were determined by performing a descriptive analysis. Then, in line with the first research model, a univariate simple linear regression analysis was performed to evaluate the individual effect of independent variables on the dependent variable. Within the scope of the second research model, a multiple linear regression analysis was performed to determine the total effect of all gender-related variables on the firm's total income. In the third research model, the age, number of customers and total capital of the audit firm were included in the model, and a multiple linear regression analysis was used again to reveal the change in the relationship between the number of women in top management and the total income of the audit organization.

\subsection{Research Variables, Model and Hypotheses}

In the study, the natural logarithm of audit service revenues and total revenues of audit firms was taken and accepted as the dependent variable. On the other hand, the age of the firm (duration of activity), the number of customers (the number of audited PIEs), the total capital amount, the number of managers and partners (Erdoğan and Kutay, 2016; Yazıc1, 2019; Sakin and Türk, 2019) the membership of 
an international audit network (IAN) and the gender of the chairperson of the board of directors were used as independent variables.

Figure 1. Research Model-1

\section{Independent variables}

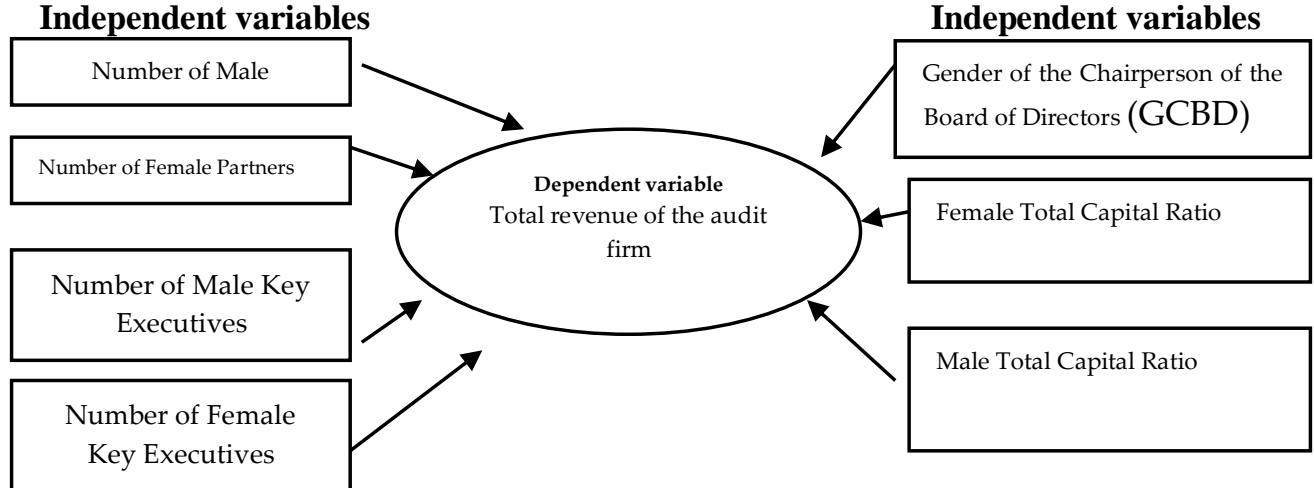

Source: Authors' computation.

Figure 1 contains a model showing the relationship between gender diversity and the dependent variable, which is the main research subject of the study. Simple linear regression analysis and an independent sample t-test were used to determine the relationship between each independent variable and the dependent variable.

\section{Figure 2: Research Model-2 INDEPENDENT VARIABLES \\ Number of Male Partners (NMP) \\ Number of Female Partners (NFP) \\ Number of Male Key Executives (NMKE) \\ Number of Female Key Executives (NFKE) \\ Gender of the Chairperson of the Board of \\ Directors (GCBD) \\ Female Total Capital Ratio (FTCR) \\ Male Total Capital Ratio (MTCR)}

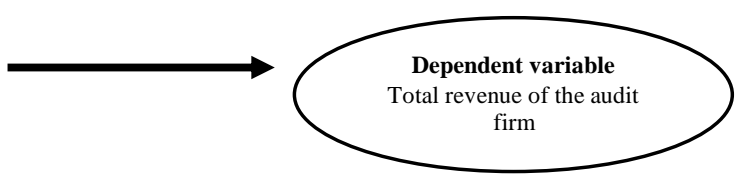

\section{Source: Authors' computation.}

Figure 2 shows the model formed to reveal the total change created by genderrelated variables on the revenue of independent audit firms. A multiple linear regression model was used to test the model. The multiple regression model created with the variables described in Figure 2 can be formulated as follows:

Total Income of the Audit Firm $=\beta_{0}+\beta_{1}(\mathrm{NMP})+\beta_{2}(\mathrm{NFP})+\beta_{3}(\mathrm{NKME})+\beta_{4}(\mathrm{NKFE})$ $+\beta_{5}(\mathrm{FTCR})+\beta_{6}(\mathrm{MTCR})+\beta_{7}(\mathrm{GCBD})+\mathrm{e}$

Figure 3 shows the model in which the variables of firm age, number of PIEs audited, the total capital amount of the firm, and membership to an IAN, which are determined to have an impact on the firm's revenue, are included in the study. 
Figure 3. Research Model-3

INDEPENDENT VARIABLES
Number of Male Partners (NMP)
Number of Female Partners (NFP)
Number of Male Key Executives (NMKE)
Number of Female Key Executives (NFKE)
Gender of the Chairperson of the Board of
Directors (GCBD)
Female Total Capital Ratio (FTCR)
Male Total Capital Ratio (MTCR)
Age of Firm (AF)
Number of Public Interest Entities (NPIE)
Total capital amount of the firm (TCAF)
Membership to an IAN

Source: Authors' computation.

In testing the model, the multiple linear regression model and independent-sample ttest were used. When the age of the audit firm, the number of customers, and its total capital were included in the model through the multivariate linear regression analysis, the relationship between the number of women in top management and the total revenue of the audit firm was examined. The multiple regression model created with the variables described in Figure 3 can be formulated as follows:

Total Income of the Audit Firm $=\beta_{0}+\beta_{1}(\mathrm{NMP})+\beta_{2}(\mathrm{NFP})+\beta_{3}(\mathrm{NKME})+\beta_{4}(\mathrm{NKFE})$ $+\beta_{5}($ FTCR $)+\beta_{6}($ MTCR $)+\beta_{7}(\mathrm{TCAF})+\beta_{8}(\mathrm{AF})+\beta_{9}$ (NPIE) $+\mathrm{e}$

\subsection{Testing the Validity of the Multiple Regression Model Used in the Study}

In the multiple linear regression model, the aim is to explain the total change in the dependent variable (the response variable) through independent variables (explanatory variables) (Kayaalp, Güney, and Cebeci, 2015). The linear regression model with one dependent variable and one independent variable is called the simple linear regression model, and the linear regression model with one dependent and multiple independent variables is called the multiple linear regression model. In order for the multiple linear regression model to be accepted as valid; the data must be suitable for multivariate normal distribution, the relationship between the dependent and independent variables must be linear, no multiple linear relationship and autocorrelation must exist between independent variables, the mean of constant variance and error terms must be zero (Kalayc1, 2014).

The natural logarithm of the data related to the dependent variable was taken in order to ensure the compatibility of the data in the study with a multivariate normal distribution. The correlation analysis was used to measure the relationship of independent variables with each other and with the dependent variable, and the Pearson correlation coefficients and significance values are shown in Table 1. A strong correlation between the independent variables means that whether or not the independent variables are included in the model will not affect the power of the 
model (Kalayc1, 2014). As the correlation values between the independent variables approach 1 , the contribution of the independent variables to the model decreases (Nakip, 2003). When Table 1 is analyzed, it is seen that the correlation between "male total capital ratio (MTCR)" and "female total capital ratio (FTCR)" variables is 1,000 , while the correlations between other variables are not strong enough to distort the model's significance. Therefore, the "MTCR" variable with a correlation value of 1,000 was excluded from the research model.

Table 1. The Pearson Correlation Values between Variables

\begin{tabular}{|c|c|c|c|c|c|c|c|c|c|c|c|}
\hline Value & & $\begin{array}{l}\text { Total } \\
\text { Income }\end{array}$ & NMP & TCAF & NFP & MTCR & FTCR & NMKE & $\mathbf{A F}$ & $\begin{array}{l}\text { NFK } \\
\text { E }\end{array}$ & $\begin{array}{l}\text { NP } \\
\text { IE }\end{array}$ \\
\hline \multirow[t]{2}{*}{ LnTotRev } & Pearson & 1 & & & & & & & & & \\
\hline & $\mathrm{p}$ & & & & & & & & & & \\
\hline \multirow[t]{2}{*}{ NMP } & Pearson & $0,336^{* *}$ & 1 & & & & & & & & \\
\hline & $p$ & ,003 & & & & & & & & & \\
\hline \multirow[t]{2}{*}{ T.S.T. } & Pearson & 0,158 & 0,188 & \multirow[t]{2}{*}{1} & & & & & & & \\
\hline & $\mathrm{p}$ & ,167 & ,099 & & & & & & & & \\
\hline \multirow[t]{2}{*}{ NFP } & Pearson & $0,577^{* *}$ & 0,376 & $-0,064$ & \multirow[t]{2}{*}{1} & & & & & & \\
\hline & $\mathrm{p}$ & ,000 & ,001 &, 576 & & & & & & & \\
\hline \multirow[t]{2}{*}{ MTCR } & Pearson & $-0,034$ & $-0,036$ & 0,057 & $-0,427$ & \multirow[t]{2}{*}{1} & & & & & \\
\hline & $\mathrm{p}$ & ,767 & ,757 & ,621 &, 000 & & & & & & \\
\hline \multirow[t]{2}{*}{ FTCR } & Pearson & 0,034 & 0,036 & $-0,057$ & 0,427 & $-1,000$ & \multirow[t]{2}{*}{1} & & & & \\
\hline & $\mathrm{p}$ & ,767 & ,757 & ,621 & ,000 & ,000 & & & & & \\
\hline \multirow[t]{2}{*}{ NMKE } & Pearson & $0,240 *$ & 0,308 & 0,072 & 0,070 & 0,118 & $-0,118$ & \multirow[t]{2}{*}{1} & & & \\
\hline & $\mathrm{p}$ &, 034 & ,006 &, 530 &, 541 &, 303 & ,303 & & & & \\
\hline \multirow[t]{2}{*}{$\mathbf{A C}$} & Pearson & $0,229^{*}$ & 0,191 & $-0,011$ & 0,235 & $-0,027$ & 0,027 & 0,215 & \multirow[t]{2}{*}{1} & & \\
\hline & $\mathrm{p}$ &, 044 & ,094 & ,922 & ,039 & ,817 & 817 & ,058 & & & \\
\hline \multirow[t]{2}{*}{ NFKE } & Pearson & $0,541^{* *}$ & 0,207 & 0,013 & 0,651 & $-0,436$ & 0,436 & 0,327 & 0,221 & \multirow[t]{2}{*}{1} & \\
\hline & $\mathrm{p}$ & ,000 & ,069 & ,912 & ,000 & ,000 & ,000 & ,001 & ,051 & & \\
\hline \multirow[t]{2}{*}{ M.S. } & Pearson & $0,631^{* *}$ & 0,370 & $-0,079$ & 0,772 & $-0,225$ & 0,225 & 0,304 & 0,219 & 0,527 & \multirow[t]{2}{*}{1} \\
\hline & $\mathrm{p}$ & ,000 & ,001 & ,490 & ,000 & 047 & ,047 & ,007 &, 054 & ,000 & \\
\hline
\end{tabular}

Note: $* * p<0,01 ; * p<0,05$

Source: Authors' computation and SPSS Output

Another assumption of the research is that there are no multiple connection problems between the independent variables. When the VIF and tolerance values obtained as a result of the analysis made to test this assumption are examined, it is determined that the VIF values vary between 1,077 and 2,991 and the tolerance statistics vary between 0,239 and 0,929. VIF values below 10 and tolerance statistics above 0.2 indicate that there are no multiple connection problems between variables. The Durbin-Watson test was used to test whether there is autocorrelation in the multiple regression model used in the study. The Durbin-Watson test value was found to be 2.157, and a value of around 1.5 - 2.5 indicates there is no autocorrelation in the model (Kalayc1, 2014).

\section{Results}


Under this heading are the findings obtained as a result of the analysis made on the general information of the audit firms within the scope of the research and the effect level of the independent variables on the dependent variable as a whole and individually. The demographic data regarding the audit firms examined within the scope of the study are summarized in Table 2:

Table 2. General Data of Audit Firms Participating in the Study $(n=79)$

\begin{tabular}{|c|c|c|c|c|c|c|c|}
\hline Variables & Category & $\mathbf{N}$ & $\%$ & Variables & Category & $\mathbf{N}$ & $\%$ \\
\hline \multirow[t]{3}{*}{ Age of Firm } & $<10$ years & 21 & 26,58 & \multirow{2}{*}{$\begin{array}{l}\text { Number of Male Key } \\
\text { Executives }\end{array}$} & $<5$ & 56 & 70,89 \\
\hline & $\begin{array}{l}10-20 \\
\text { years }\end{array}$ & 31 & 39,24 & & $>5$ & 23 & 29,11 \\
\hline & $>20$ years & 27 & 34,18 & $\begin{array}{l}\text { Number of Female } \\
\text { Key Executives }\end{array}$ & $<5$ & 79 & 100 \\
\hline \multirow[t]{3}{*}{ Number of Male Partners } & 0 & 0 & 0 & \multirow{4}{*}{$\begin{array}{l}\text { Male Common } \\
\text { Capital Ratio }\end{array}$} & $<\% 10$ & 3 & 3,80 \\
\hline & $<10$ & 59 & 74,68 & & $\% 10-\% 49,99$ & 2 & 2,53 \\
\hline & $>=10$ & 20 & 25,32 & & $\% 50-\% 90$ & 8 & 10,13 \\
\hline \multirow[t]{3}{*}{ Number of Female Partners } & 0 & 47 & 59,49 & & $\% 91-\% 100$ & 66 & 83,54 \\
\hline & $0<x<10$ & 31 & 39,24 & \multirow{4}{*}{$\begin{array}{l}\text { Female Total Capital } \\
\text { Ratio(n }\end{array}$} & $<\% 10$ & 66 & 83,54 \\
\hline & $>=10$ & 1 & 1,27 & & $\begin{array}{l}\% \quad 10-\% \\
49,99\end{array}$ & 8 & 10,13 \\
\hline \multirow{2}{*}{$\begin{array}{l}\text { Gender of the Chairman of } \\
\text { the Board of Directors }\end{array}$} & Female & 4 & 5,1 & & $\% 50-\% 90$ & 2 & 2,53 \\
\hline & Male & 75 & 94,9 & & $\% 91-\% 100$ & 3 & 3,80 \\
\hline \multirow{2}{*}{$\begin{array}{l}\text { Membership of a Global } \\
\text { Auditing Network }\end{array}$} & Yes & 43 & 54,4 & \multirow{2}{*}{$\begin{array}{l}\text { Country of affiliation } \\
(\mathrm{n}=43)\end{array}$} & Anglo-Saxon & 34 & 79,06 \\
\hline & No & 36 & 45,6 & & $\begin{array}{l}\text { Continental } \\
\text { Europe }\end{array}$ & 9 & 20,94 \\
\hline \multirow{5}{*}{$\begin{array}{l}\text { Number of Public Interest } \\
\text { Entities }\end{array}$} & $<10$ & 61 & 77,22 & & & & \\
\hline & $10-50$ & 14 & 17,72 & & & & \\
\hline & $51-100$ & 0 & 0 & & & & \\
\hline & $100-250$ & 1 & 1,26 & & & & \\
\hline & $>250$ & 3 & 3,80 & & & & \\
\hline
\end{tabular}

Source: Authors' computation and SPSS Output

As seen in Table 2, 26.58\% of the audit firms are in operation for less than 10 years; $39.24 \%$ for $10-20$ years, and $34.18 \%$ for more than 20 years. In addition, it is observed that the number of male partners in the audit firms within the scope of the research is higher $(74.68 \%)$, and there are no female partners in more than half of the audit firms (59.49\%); women hold the chairmanship of the board of directors in only $5.1 \%$ of them, and the number of female managers in key management positions is below five across all the audit firms. Male shareholders are dominant in terms of capital shares $(83.54 \%)$. Except for the gender variable, $54.4 \%$ of the audit firms included in the research are members of an international audit network and the majority (79.06\%) are affiliated with countries implementing the Anglo-Saxon accounting system. As of 2018, it is seen that the majority of audit firms have fewer than 50 customers in terms of the number of PIEs they audit.

In line with the main purpose of the study, the univariate linear regression analysis was conducted to reveal the effect of each of the gender-related independent variables on the total revenues of the audit firms. The independent sample t-test was conducted in order to reveal whether there is a significant difference between the total revenues of the audit firms in relation to the variable of the "Gender of the 
Chairperson of the Board of Directors". The findings obtained as a result of the univariate regression analysis are summarized and combined in Table 3.

\begin{tabular}{lllllllll}
\multicolumn{7}{l}{ Table 3. Findings from the Univariate Regression Analysis } \\
$\begin{array}{l}\text { Independent } \\
\text { variable }\end{array}$ & $\mathbf{R}$ & $\begin{array}{l}\text { R- } \\
\text { Square }\end{array}$ & $\begin{array}{l}\text { Adjusted } \\
\text { R- } \\
\text { Square }\end{array}$ & $\mathbf{F}$ & $\begin{array}{l}\text { Level of } \\
\text { Significance }\end{array}$ & $\begin{array}{l}\text { Durbin- } \\
\text { Watson }\end{array}$ & $\begin{array}{l}\text { Estimated } \\
\text { Coefficient } \\
\text { Value }\end{array}$ \\
\hline NMP & 0,336 & 0,113 & 0,101 & 9,686 & $0,003^{*}$ & 1,628 & 0,046 \\
NFP & 0,577 & 0,332 & 0,324 & 37,853 & $0,000^{*}$ & 1,905 & 0,203 \\
NMKE & 0,240 & 0,058 & 0,045 & 4,647 & $0,034^{* *}$ & 1,589 & 0,050 \\
NFKE & 0,541 & 0,293 & 0,284 & 31,524 & $0,000^{*}$ & 1,992 & 0,529 \\
\hline
\end{tabular}

Note: $N M P=$ Number of Male Partners; NFP = Number of Female Partners; NMKE= Number of Male Key Executives; NFKE = Number of Female Key Executives; * $p<0,01$; ** $p<0.05$

Source: Authors' computation and SPSS Output

Table 3 shows the effect of the change in each gender-related variable on the total revenue of the audit firm, the significance of the univariate regression models established, and how many units the one-unit increase in the independent variables increases the total revenue of the audit firm. Accordingly, $11.3 \%$ of the change in the total revenue of the audit firm is explained by the changes in the NMP, 33.2\% by the changes in the NFP, $5 \%$ by the changes in the NMKE, and $29.3 \%$ by the changes in the NFKE. The established models seem to be significant (significance levels $<0.05$ ). A one-unit increase in the NMP constitutes an increase of 0.046 unit; a one-unit increase in the NFP, an increase of 0.203 unit; a one-unit increase in the NMKE, an increase of 0.050 unit; and a one-unit increase in the NFKE, an increase of 0.529 unit in the revenue of the audit firm. As a result, under the assumption that all other variables are constant; the changes in the number of female partners and female key executives in the audit firms account for $33.2 \%$ and $29.3 \%$ of the change in the total revenue of the audit firms.

The independent sample t-test was conducted in order to test whether there is a significant difference between the total revenues of the audit firms in relation to the variable of the "Gender of the Chairperson of the Board of Directors", which is another variable related with gender. However, it was determined that there are 3 female board chairpersons versus 75 male board chairpersons in the analysis. It was concluded that the independent sample t-test result would not be healthy since the numbers of the variables were not approximate to each other. In order to reveal the total change created by gender-related independent variables on the dependent variable, model 2 was created and the multiple linear regression analysis was performed. The coefficients for the variables used are shown in Table 4. In the gender-related multivariate regression model, it is seen that the independent variables of "number of female partners", "female capital ratio" and "number of female key executives" have an impact on the total revenues of the audit firms. As a result of multiple regression analysis, it was determined that the number of female 
partners $(\beta=0.151, p<0.05)$ and the number of female key executives $(\beta=0.360$, $\mathrm{p}<0.05)$ statistically significantly and positively affected the total revenues of the audit firms; however, the female capital ratio $(\beta=-0.011, p<0.05)$ negatively affected the revenue of the audit firms. The summary of the gender-related multiple linear regression model is shown in Table 5. Table 5 shows the total change created by the variables (Number of Male Partners, Number of Female Partners, Male Total Capital Ratio, Female Total Capital Ratio, Number of Male Key Executives, Number of Female Key Executives and Gender of the Chairperson of the Board of Directors), which are considered as gender-related independent variables within the scope of the analysis, on the total revenue of the audit firm and the significance of the model established. Accordingly, $47.7 \%$ of the change on the audit firm's total revenue is explained by gender variables.

Table 4. Coefficients in the Gender-related Multivariate Linear Regression Analysis

\begin{tabular}{|c|c|c|c|c|c|c|}
\hline \multirow[t]{2}{*}{ Model } & \multicolumn{2}{|c|}{$\begin{array}{l}\text { Non-Standardized } \\
\text { Coefficients }\end{array}$} & \multirow{2}{*}{$\begin{array}{l}\text { Standardized } \\
\text { Coefficients } \\
\text { Beta }\end{array}$} & \multirow{2}{*}{ t value } & \multirow{2}{*}{\multicolumn{2}{|c|}{ Tolerance VIF }} \\
\hline & B & Std. Error & & & & \\
\hline Number of Male Partners &, 014 & ,014 &, 104 & $1,043,300$ &, 749 & 1,335 \\
\hline Number of Female Partners & 151 &, 045 & 429 & 3,336,001* & ,447 & 2,238 \\
\hline Female Total Capital Ratio &,- 011 & ,004 &,- 314 & $-2,665,010^{*}$ &, 530 & 1,885 \\
\hline $\begin{array}{l}\text { Number of Female Key } \\
\text { Executives }\end{array}$ & ,360 & , 140 & ,369 & 2,579,012* & 361 & 2,773 \\
\hline Number of Male Key Executives & ,004 & 022 & ,021 & 200, 842 & ,650 & 1,538 \\
\hline $\begin{array}{l}\text { Gender of the Chairperson of the } \\
\text { Board of Directors }\end{array}$ &,- 017 & ,433 &,- 005 & -,039, 969 & ,460 & 2,175 \\
\hline
\end{tabular}

Note: $*$ Significant at level $p<0.05$

Source: Authors' computation and SPSS Output

Table 5. Findings from the Multiple Linear Regression Analysis

\begin{tabular}{lllllllll}
\hline $\begin{array}{l}\text { Independent } \\
\text { variable }\end{array}$ & $\mathbf{R}$ & $\begin{array}{l}\text { R- } \\
\text { Square }\end{array}$ & $\begin{array}{l}\text { Adjusted } \\
\text { Square }\end{array}$ & R- & F & $\begin{array}{l}\text { Level } \\
\text { Significance }\end{array}$ & of & $\begin{array}{l}\text { Durbin- } \\
\text { Watson }\end{array}$ \\
\hline $\begin{array}{l}\text { Gender-related } \\
\text { Variables }\end{array}$ & 0,690 & 0,477 & 0,432 & 10,774 & 0,0001 & 2,130 \\
\hline
\end{tabular}

Source: Authors' computation and SPSS Output

It is obvious that, in addition to the gender-related independent variables, the variables of the number of PIEs audited by the audit firm, the age of the firm, the total capital amount and membership of an international audit network are also influential on the total revenues of the audit firms. When these variables were included in the model, the multiple linear regression analysis was performed in order to determine the extent of change created by gender-related independent variables on the total revenue. The findings are summarized in Table 6.

Table 6. Coefficients in the Multivariate Linear Regression Analysis

\begin{tabular}{lcc|c|cccr}
\hline Model & \multicolumn{2}{c}{$\begin{array}{c}\text { Non-Standardized } \\
\text { Coefficients }\end{array}$} & $\begin{array}{c}\text { Standardized } \\
\text { Coefficients }\end{array}$ & & & & \\
\hline Age of Firm & B & Std. Error & Beta & t value & p & Tolerance VIF \\
\hline &, 004 &, 006 &, 061 &, 683 &, 497 &, 901 & 1,110
\end{tabular}


Total Capital

Number of Male Partners

Number of Female Partners

Number of Male Key

Executives

Number of Female Key

Executives

Number of Public Interest

Entities

\begin{tabular}{cc|c}
$4,389 \mathrm{E}-7$ &, 000 &, 183 \\
, 009 &, 014 &, 067 \\
, 008 &, 061 &, 023 \\
,- 007 &, 022 &,- 035 \\
& &, 265 \\
, 259 &, 120 &, 460
\end{tabular}

1,077

1,412

4, 178

$\begin{array}{llll}-, 329,628 & 1,593\end{array}$

$2,161, \mathbf{0 3 4} * * \quad, 470 \quad 2,130$

$3,159 \quad, 002 * \quad 334 \quad 2,991$

Note: $* P<0.01 ; * * p<0.05$ show significance levels.

Source: Authors' computation and SPSS Output

It is observed that the independent variables of total capital amount, number of female key executives, and number of PIEs (number of customers) in the multivariate regression model have an impact on the total revenues of independent audit firms. As a result of the multiple regression analysis, it was determined the total capital amount $(\beta=0.183, p<0.05)$, the number of female key executives $(\beta=0.265, p<0.05)$ and the number of PIEs audited $(\beta=0.460, p<0.01)$ statistically and positively affected the total revenue of the audit firms. The summary of the multivariate regression model is shown in Table 7.

Table 7. The Summary of the Multivariate Regression Model

\begin{tabular}{lllllll}
\hline Model & R & R-Square & $\begin{array}{l}\text { Adjusted } \\
\text { R-Square }\end{array}$ & F & Level of Significance & Durbin-Watson \\
\hline 1 & 0,710 & 0,504 & 0,455 & 10,175 & 0,000 & 2,157 \\
\hline
\end{tabular}

Source: Authors' computation and SPSS Output.

According to Table 7, the independent variables in the multivariate regression model explain $50.4 \%$ of the change in the total revenues of the audit firms. In the univariate regression model (Table 3), the number of male partners, the number of female partners, and the number of male key executives have lost their meaning in the multivariate regression model, although they have created a change in the total revenue of the audit firms. Even when the effects of gender-unrelated independent variables of firm age, total capital amount, and number of PIEs audited are included in the model, the independent variable of "number of female key executives" continues to be statistically significant at $5 \%$ significance level $(\mathrm{p}=0.034)$. Another gender-unrelated independent variable, addressed within the scope of the study, is the IAN membership of audit firms. The independent sample t-test was conducted to determine whether the audit firms' IAN membership makes any significant difference on their total revenue, and the findings obtained are summarized in Table 8 . Table 8 shows that the fact that audit firms' IAN membership creates a statistically significant difference in their total revenues, $t(76)=4.382, \mathrm{p}<0.01$. Whether there is a significant difference in the total revenue of the audit firms in terms of the international audit network which they are members of is analyzed by the independent sample t-test. The findings are summarized in Table 9. 
Table 8. Findings from the Independent Sample t-test

\begin{tabular}{lllllll}
\hline Membership to an International Auditing Network & N & Mean & S & sd & t & P \\
\hline Yes & 43 & 6,54 & 0,72 & 76 & 4,382 & 0,000 \\
No & 35 & 5,94 & 0,38 & & & \\
\hline
\end{tabular}

Source: Authors' computation and SPSS Output

Table 9. Findings Obtained from the Independent Audit Firms

\begin{tabular}{lllllll}
\hline Country & N & Mean & S & sd & t & P \\
\hline Anglo-Saxon & 34 & 6,54 & 0,73 & 41 & 0,052 & 0,959 \\
Continental Europe & 9 & 6,53 & 0,73 & & & \\
\hline
\end{tabular}

Source: Authors' computation and SPSS Output.

According to Table 9, it was observed that 43 audit firms with IAN memberships did not have a statistically significant difference in their total revenues in terms of the country they are affiliated with, $\mathrm{t}(41)=0.052 \mathrm{p}>0.01$.

In brief, as a result of the analyzes conducted to determine gender mainstreaming on the total revenues of independent audit firms, it was observed that each of the gender-related independent variables created a statistically significant effect on the total revenue and that the variables related to "males" lost its significance when gender-related variables were taken as a whole. In addition, when independent variables such as firm age, number of customers (number of PIEs audited), total capital amount, membership to an IAN, etc. were added to gender-related variables, it was determined that only the variable of "number of female key executives" remained significant and sustained its effect. The variable of "number of female partners" had the biggest effect among the gender-related independent variables (number of male partners, number of female partners, number of male key executives, and number of female key executives) included in the univariate regression model. This variable is followed by the "number of female key executives". The independent variables included in the gender-related multivariate regression model (model-2) had an impact of $47.7 \%$ on the firm's total revenue, while the independent variables in the multivariate regression model (model-3), including gender-unrelated variables, had an impact of $50.4 \%$ on the audit firm's total revenue. In other words, $50.4 \%$ of the change in the total revenue is provided by the independent variables included in the model.

\section{Discussion}

This study demonstrates the effect of the female executives in the independent audit sector on the total revenue of the independent audit firm they work in. Gender diversity in the key management team, partnership structure, and the board of directors of the independent audit firms is the main focus of the study. While the individual change effects of the variables set on the total revenue of the audit firm were determined by the univariate regression analysis, the total effect was tested by the multiple regression analysis. Additionally, by adding variables such as the 
number of customers (number of PIEs), firm age, total capital amount, etc. to gender-related variables, the change in the effect was observed.

There are three models in the study. When the first model was analyzed, it was seen that each of the gender-related variables (number of male partners, number of female partners, number of male key executives, and number of female key executives) individually had a positive and significant effect on the revenue of the audit firm. In the study, seven different gender-related variables were determined. When the total effect of these variables on the audit firm's total revenue was analyzed, it was observed that the number of male partners and the number of male key executives lost their significance. It is noteworthy that the number of female partners and the number of female key executives had a positive impact on the firm's total revenue. On the other hand, the capital shares of female partners in the independent audit firm had a negative effect on the firm's total revenue. Indeed, this result is in accord with that found by Yang et al. (2019). The only negative effect detected belongs to this variable. In addition, the gender-related variables created a $47.7 \%$ change in the firm's total revenue. This can be regarded as a high rate since it almost constitutes half of the ratio.

However, it is obvious that many other variables are also influential on the firm's total revenue, apart from gender-related variables. Some other variables, which can be obtained from the transparency reports of the audit firms and whose effects have been demonstrated through various studies, are also included in the study. When variables such as the number of customers, firm age, and membership to an international audit network, which have a significant impact on revenue, are included in the analysis, it is observed that only the variable of "number of female key executives" remained significant. This result shows that the presence of female representatives in key management positions of independent audit firms positively affects the firm's revenues. Similar to the results from the vast majority of the studies in domestic and international literature, a positive effect was found in this study. A similar study was conducted by Bozcuk. The common point with the study in question is that they are sector-oriented. While Bozcuk included only the "cap auditor" position as "top management staff" in his analysis, in this study, the variables of "partnership structure (in terms of gender)", "key management staff (in terms of gender)" and "gender of the board chairperson" were included in the analysis. Contrary to the results obtained from the study in question, in this study, the impact of female representatives in independent audit firms on the total revenues of audit firms did not lose its significance despite some other variables (Bozcuk, 2018).

It is obvious that the subject of "encouraging women leaders" determined within the scope of the "gender mainstreaming" target, which is among the Sustainable Development Goals of 2030, has been making progress day by day. It is also supported by the studies carried out that women's employment increases gradually in business life, but the number of women executives is not at the desired level yet. In 
this regard, ensuring that especially women leaders and executives are included in the structure of the firm will contribute to the welfare of the country as well as the development of the firms. For this purpose, women should be prevented from experiencing glass ceiling syndrome. The male-dominant understanding in the society should be replaced by the understanding of "equality between men and women" and the understanding that women can succeed in any field that does not require physical power.

\section{References:}

Ahmadi, A., Nakaa, N., Bouri, A. 2018. Chief Executive Officer attributes, board structures, gender diversity and firm performance among French CAC 40 listed firms. Research in International Business and Finance, (44), 218-226.

Alhan, O., Yüksel, S. 2018. Kadın Çalışanların Banka Büyüklügü Ve Karlılığına Etkisi: Engle Granger Eş Bütünleşme Analizi İle Türkiye Üzerine Bir Uygulama. Journal of Behavior at Work, 3(2), 140-147.

Atılgan, Ö. 2017. Yönetim Kurulu Büyüklüğü, Bağımsız Üye Oranı Ve Kadın Üye Oranı İle Finansal Performans İlişkisi. Dokuz Eylül Üniversitesi İktisadi ve İdari Bilimler Fakültesi Dergisi, 32(2), 315-354.

Bozcuk, A. 2018. Türkiye'deki Bağımsız Denetim Kuruluşlarında Üst Düzeydeki Cinsiyet Çeşitliliği ve Gelir Etkisi. Uluslararası Sosyal Araştırmalar Dergisi / The Journal of International Social Research, 11(59), 882-890.

Chauhan, Y., Dey, D. 2017. Do female directors really add value in Indian firms? Journal of Multinational Financial Management, (42-43), 24-36.

Conyon, M.J., He, L. 2017. Firm performance and boardroom gender diversity: A quantile regression approach. Journal of Business Research, 79(C), 198-211.

Dresner, S. 2002. The Principles of Sustainability. UK: Earthscan.

Erdoğan, S., Kutay, N. 2016. Türkiye'de Bağımsız Denetim Şirketlerinin Karakteristiklerinin Bağımsız Denetim Gelirleri Üzerindeki Etkisi. Int. Journal of Management Economics and Business, 12(27), 105-122. doi:http://dx.doi.org/10.17130/10.17130/ijmeb.2016.12.27.1053.

GAP. 2002. The Southeastern Anatolia Project (GAP): Retrieved from: http://www.gap.gov.tr/gap-surdurulebilir-kalkinma-programi-sayfa-28.html.

Green, C., Homroy, S. 2018. Female directors, board committees and firm performance. European Economic Review, (102), 19-38.

Kalaycı, Ş. 2014. SPSS Uygulamalı Çok Değişkenli İstatistik Teknikleri, 7th ed.; Asil Yayınları, Türkiye, 2014 (7th Edition b.). Ankara: Asil Yayınları.

Kallianiotis, N.I., Bianchi, K., Arize, C.A., Malindretos, J., Ndu, I. 2020. Financial Assets, Expected Return and Risk, Speculation, Uncertainty, and Exchange Rate Determination. European Research Studies Journal, 23(3), 3-30. DOI: $10.35808 / \mathrm{ersj} / 1622$.

Karabıyık, İ. 2012. Türkiye'de Çalışma Hayatında Kadın İstihdamı. Marmara Üniversitesi İktisadi ve İdari Bilimler Dergisi, 32(1), 231-260.

Karayel, M., Doğan, M. 2014. Yönetim Kurulunda Cinsiyet Çeşitliliği ve Finansal Performans İlişkisi: BIST 100 Şirketlerinde Bir Araştırma, 19(2), 75-88.

Kavas, A. 2018. Karşılaştırmalarla 81 İl İçin Toplumsal Cinsiyet Eşitliği Karnesi. Ankara: TEPAV: Retrieved from: https://www.tepav.org.tr/upload/files/15204026327.Karsilastirmalarla_81_Il_Icin_Toplumsal_Cinsiyet_Esitligi_Karnesi_2018.pdf. 
Kayaalp, G., Güney, M., Cebeci, Z. 2015. Variable Selection in Multiple Regression Model Application of Animal Science. Journal Of Cukurova University Agricultural Faculty, 30(1), 1-8.

Liu, Y., Wei, Z., Xie, F. 2014. Do women directors improve firm performance in China? Journal of Corporate Finance, (28), 169-184.

Li, X., Li, Y. 2020. Female independent directors and financial irregularities in chinese listed firms: From the perspective of audit committee chairpersons. Finance Research Letters, 32.

Martínez, M., Rambaud, S. 2019. Women on corporate boards and firm's financial performance. Women's Studies International Forum, (76).

Menteş, S. 2011. Gender Diversity at the Board and Financial Performance: A Study on ISE (Istanbul Stock Exchange). Middle Eastern Finance and Economics, 6-15.

MFA. 2002. Republic of Turkey Ministry of Foreign Affairs: Retrieved from: http://www.mfa.gov.tr/dunya-surdurulebilir-kalkinma-zirvesi_johannesburg_-26agustos---4-eylul-2002_.tr.mfa.

Nakip, M. 2003. Pazarlama Araştırmaları: Teknikler ve (SPSS Destekli) Uygulamalar. Ankara: Seçkin Yayınları.

Nas, T.İ., Özden, M., Okan, T. 2019. Türk İşleme Gruplarının Bağlı Kuruluşlarında Kadın Ortak Yönetim Kurulu Üye Profili. XVIII. International Business Congress. Osmaniye: Osmaniye Korkut Ata University.

Ocak, M. 2013. Yönetim Kurulu ve Üst Yönetimde Yer Alan Kadınların Finansal Performansa Etkisi”, Türkiye'ye İlişkin Bulgular. Ekim, 107-126.

Özataç, N. 2011. Gender Diversity in Board of Directors and Top Management: The Case of Turkish Bank, (115), 311-319.

Postula, M., Irodenko, O., Dubel, P. 2020. Internal Audit as a Tool to Improve the Efficiency of Public Service. European Research Studies Journal, 23(3), 699-715. DOI: $10.35808 /$ ersj/1663.

Rovers, L. 2011. Women on boards and firm performance. Journal of Management \& Governance, (17), 491-509.

Sakin, İ., Türk, Z. 2019. Bağımsız Denetim Kalitesi Açısından Bağımsız Denetim Kuruluşlarının Özellikleri ve Denetim Gelirleri: Bağımsız Denetim Kuruluşları Üzerine Bir Araştırma. Business \& Management Studies: An International Journal, 7(3). doi:https://doi.org/10.15295/bmij.v7i3.1239

Savaşkan, E. 2020. Yönetim Kurulunda Toplumsal Cinsiyet Eşitsizliğine Yönelik Olarak BIST 100'de Yer Alan İmalat Sanayii Firmalarının Finansal Açıdan Değerlendirilmesi. Ankara Üniversitesi Sosyal Bilimler Dergisi, 11(1), 41-48.

UNDP TR. 2016. Retrieved from UNDP Turkey: https://www.tr.undp.org/content/turkey/tr/home/sustainable-development-goals.html

Yang, P., Riepe , J., Moser, K., Pull, K., Terjesen, S. 2019. Women directors, firm performance, and firm risk: A causal perspective. The Leadership Quarterly, 5(30 (101297)), 1-15.

Yazic1, N. 2019. The Determination of The Factors Effecting The Revenues of Independent Audit Firms in Turkey Through The Analysis of Transparency Reports. Gümüşhane Üniversitesi Sosyal Bilimler Enstitüsü Elektronik Dergisi, 10(1), 168-180. https://dergipark.org.tr/tr/pub/gumus/issue/44146/485966. 